\title{
DETERMINING IRRIGATION SCHEDULING AND DIFFERENT MANURE SOURCES OF YIELD AND NUTRITION CONTENT ON MAIZE (ZEA MAYS L.) CULTIVATION
}

\author{
DOGAN, $\mathrm{Y}^{{ }^{*}}{ }^{*}$ TOGAY, $.^{2}-$ TOGAY, Y. ${ }^{2}$ \\ ${ }^{1}$ Kiziltepe Vocational High School, Mardin Artuklu University, 47000 Mardin, Turkey \\ ${ }^{2}$ Fethiye ASMK Vocational High School, Mugla S. K. University, 48300 Mugla, Turkey \\ *Corresponding author \\ e-mail: doganyyu@hotmail.com
}

(Received $8^{\text {th }}$ Aug 2018; accepted $16^{\text {th }}$ Jan 2019)

\begin{abstract}
The aim of this study was to determine the most suitable irrigation schedules and sources of manure for maize under Mardin ecological conditions. For this purpose, four sources of fertilizer and three irrigation schedules were applied in hybrid maize cultivar to find out their effects on the yield and yield factors in the years of 2014 and 2015. The study used a randomized complete block with split block design with 3 replications. In the study, significant differences were determined on traits at the level of $1 \%$ and $5 \%$. The plant height, first cob height, cob length, number of seeds per cob, cob yield, 1000 seed weight, seed yield per unit, hectoliter, protein and oil ratio in seed, $\mathrm{Mg}, \mathrm{K}, \mathrm{Fe}, \mathrm{Ni}, \mathrm{Cu}, \mathrm{Zn}, \mathrm{Mn}, \mathrm{Na}, \mathrm{Ca}$ content of seeds were significantly influenced by irrigation schedules and sources of fertilizer for two years. The highest values were obtained from chicken manure with $9646 \mathrm{~kg} \mathrm{ha}^{-1}$ in the first year and $11019 \mathrm{~kg} \mathrm{ha}^{-1}$ in the second year, whereas the lowest values were obtained from control with 6363 and $6662 \mathrm{~kg} \mathrm{ha}^{-1}$ for the first year and the second, respectively. But the difference between $180-80 \mathrm{~kg} \mathrm{~N}-\mathrm{P}_{2} \mathrm{O}_{5}-$ $\mathrm{ha}^{-1}$ and chicken manure was not statistically significant in the second year. According to the irrigation schedules, the grain yield ranged between $6386-10678 \mathrm{~kg} / \mathrm{ha}$ in the first year and $7575-12133 \mathrm{~kg} \mathrm{ha}^{-1}$ in the second year. The lowest grain yield per area was from the four-irrigation application, whereas the highest values were obtained from the six-irrigation application. The results of the study showed that grain yield and nutrient level of corn seeds increased, depending on irrigation time and number.
\end{abstract}

Keywords: Zea mays, water application, organic and inorganic fertilizer, macro and micro element, yield

\section{Introduction}

Maize is a widely cultivated grain cereal for food consumption on the global scale with 183 million hectares and 1.031 million tons of worldwide production. The area sown in Turkey is 6.390 .000 hectares and it produces 5.900.000 tons. Average global yield per year is $563 \mathrm{~kg} \mathrm{ha}^{-1}, 9230 \mathrm{~kg} \mathrm{ha}^{-1}$ for Turkey (FAO, 2017). Maize is a major crop for both direct and indirect human consumption as it forms a major energy feed for livestock. It is a cheap source of raw material for various agricultural industries and extensively used for preparation of corn starch.

Appropriate development and growth of maize need favorable moisture in root zone. The amount of moisture in the soil decreases in time during dry seasons. Limited water supply during the growing season results in soil and plant water deficits, causing a decrease in maize yields (Gordon et al., 1995; Patel et al., 2006). Timing and supplemental irrigation is important in irrigation scheduling for the most effective use of available water in optimizing maize production. Water deficit affects timing of emergence, number of leaves per plant but delays tasseling initiation and silking, 
reduces plant height and vegetation growth of maize (Abrecht and Carberry, 1993; Singh et al., 2007).

The constant use of chemical fertilizers leads to hazards concerning health and environment (Pimentel et al., 1996). The importance of the use of organic manures under low input agricultural systems has been the subject of many studies. Majority of these studies aim at improving the quality and fertility of soil (DeJager et al., 2001; Palm et al., 2001). Manure can serve as a source of significant nutrient element which includes P and N (Gilley and Eghball, 2002). The application of manure to land give rise to similar results to those obtained when inorganic fertilizers are applied (Eghball and Power, 1999). The amount of organic matter in manure can significantly increase soil aggregation, structure and water holding capacity, infiltration, microbial activity, and can reduce erosion and soil compaction (Haynes and Naidu, 1998; Gilley and Risse, 2000). Poultry manure is relatively a cheap source of macro and micro nutrients (N, P, $\mathrm{K}, \mathrm{Ca}, \mathrm{Mg}, \mathrm{S}, \mathrm{Cu}, \mathrm{Fe}, \mathrm{Mn}, \mathrm{B})$. It has the potential to increase soil carbon and $\mathrm{N}$ content, soil porosity and enhance microbial activity. The hazards of chemical fertilizers, which occurred in heavy and unbalanced ways, led to the use of organic manures in intensively growing areas for sustainable production system. Therefore, in order to sustain the land and achieve potential crop production, careful use of organic manures has become important scientifically. It must be stressed that the importance of farm yard manure, vermicompost, chicken manure and green leaf manure in soil improvement depends on their nutrient content. It helps the improvement of soil structure and water holding capacity (Kale and Bano, 1986; Srivastava, 1998).

The aim of this research is to determine the effects of irrigation scheduling and different manure sources on yield and nutrition content in maize cultivation.

\section{Materials and Methods}

This trial was conducted to determine the most suitable irrigation schedules and sources of manure in a well-adapted maize (Zea mays L.) Farw. cultivar Limagrain Helen, in 2014 and 2015 in the fields of Kiziltepe Vocational High School of Mardin Artuklu University (longitude $40^{\circ} 57^{\prime} 59.01^{\prime \prime} \mathrm{E}$, latitude $37^{\circ} 07^{\prime} 34.74 \mathrm{~N}$, and altitude $494.0 \mathrm{~m}$ ) (Figure 1). Cultivar Limagrain Helen is intensively grown as a kind of grain maize in the region.

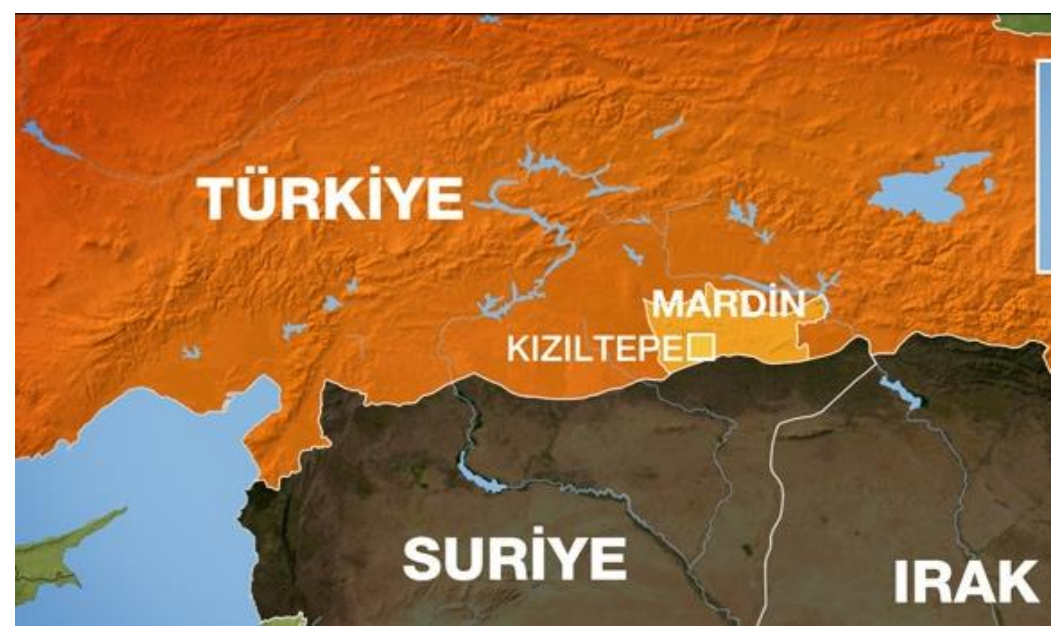

Figure 1. The research was conducted in Kiziltepe/Mardin of Turkey 
In 2014 and 2015, precipitation throughout the season was $158.6 \mathrm{~mm}$ and $133.6 \mathrm{~mm}$ respectively, and the average over the long-term for the same period was $111.1 \mathrm{~mm}$ (Table 1).

Table 1. Meteorological data for the growing seasons of 2014, 2015 and long-term averages in Mardin, Turkey (TSMS, 2016)

\begin{tabular}{|c|c|c|c|c|c|c|c|c|c|}
\hline & \multicolumn{3}{|c|}{ Precipitation (mm) } & \multicolumn{4}{|c|}{ Average temperature $\left({ }^{\circ} \mathrm{C}\right)$} & \multicolumn{2}{|c|}{ Relative humidity (\%) } \\
\hline Months & 2014 & 2015 & LTA* & 2014 & 2015 & LTA* & 2014 & 2015 & LTA* \\
\hline June & 1.4 & 2.9 & 4.1 & 25.9 & 25.9 & 25.7 & 22.5 & 29.0 & 32.3 \\
\hline July & 1.0 & 0.2 & 1.1 & 30.4 & 31.6 & 29.9 & 20.0 & 19.6 & 27.7 \\
\hline August & 7.0 & 0.4 & 0.5 & 31.3 & 30.5 & 29.6 & 17.1 & 25.8 & 28.4 \\
\hline September & 10.8 & 9.9 & 1.9 & 24.3 & 28.4 & 25.1 & 31.2 & 23.0 & 32.6 \\
\hline October & 42.8 & 58.2 & 32.6 & 18.1 & 19.5 & 18.4 & 47.2 & 49.6 & 45.1 \\
\hline November & 95.6 & 62.0 & 70.9 & 10.2 & 11.7 & 10.9 & 53.1 & 50.3 & 57.0 \\
\hline Total & 158.6 & 133.6 & 111.1 & & & & & & \\
\hline Average & & & & 23.4 & 24.6 & 23.3 & 31.9 & 32.9 & 37.2 \\
\hline
\end{tabular}

*LTA = Long-term average (1960-2015)

Average temperature was $23.54^{\circ} \mathrm{C}$ in 2014 and $24.6^{\circ} \mathrm{C}$ in 2015 . There was an increase in average temperature when it is compared to long term average of $23.3^{\circ} \mathrm{C}$. Average relative humidity was $31.9 \%$ in the first and $32.9 \%$ in the second vegetation periods (TSMS, 2016) and $37.2 \%$ for the long term. The soil, in which this study carried out, is classified as entisols according to soil taxonomy (Soil Survey Staff, 1999). The results of calcareous soil analysis are as follows: sandy loam texture, very low organic matter and moderate in available phosphorus (Table 2).

The experiment was laid out in a randomized complete block design (RCBD) with split-plot arrangement keeping the irrigation schedules in main plots and integrated manure sources in sub plots. The experiment was replicated three times. The net plot size was $5 \mathrm{~m} \times 2.8 \mathrm{~m}$.

Table 2. Some properties of the $<2 \mathrm{~mm}$ fraction of the top $30 \mathrm{~cm}$ of soil used for site

\begin{tabular}{c|c}
\hline Soil properties & Site \\
\hline Texture & sandy loam \\
$\mathrm{pH}^{\mathrm{A}}$ & 7.59 \\
${\mathrm{Clay}(\%)^{\mathrm{B}}}^{\mathrm{CaCO}}(\%)^{\mathrm{C}}$ & 29.6 \\
$\mathrm{CaCO}_{3}$ & 18.9 \\
Olsen soil test $\mathrm{P}(\mathrm{ppm})^{\mathrm{D}}$ & 57.8 \\
Total Salt $(\%)^{\mathrm{E}}$ & 0.059 \\
Organic matter $(\%)^{\mathrm{F}}$ & 1.59 \\
\hline
\end{tabular}

${ }^{\mathrm{A}} 1: 2.5$ soil:water, ${ }^{\mathrm{B}}$ Bouyoucos (1951), ${ }^{\mathrm{C}}$ lime by calcimetric methods, ${ }^{\mathrm{D} O l s e n}$ et al. (1954), ${ }^{\mathrm{E}}$ Richard (1954), FJackson (1962)

The treatments were three irrigation schedules i.e. I1: four irrigations (1st at three leaf stage, 2 nd at ninth-leaf stage, $3 \mathrm{rd}$ at tasseling stage, 4th at milking stage), I2: five irrigations (1st at fourth leaf stage, 2nd at ninth leaf stage, 3rd at tasseling, 4th at milking stage, 5th at dough stage) and I3: six irrigations (1st at third leaf stage, 2nd at ninth leaf stage, 3rd at tasseling, 4th at blister stage, 5th at milking stage, 6th at dough stage) and four manure (M0: control, M1: 180-80 kg N-P $\mathrm{O}_{5}-\mathrm{ha}^{-1}, \mathrm{M} 2$ : Chicken manure $15 \mathrm{t} \mathrm{ha}^{-1}$ and M3: Farmyard manure $15 \mathrm{t} \mathrm{ha}^{-1}$ ). Manure and irrigation were applied 
according to the treatments. All other agronomic practices were kept normal and uniform for all treatments. Observations on growth and yield parameters were recorded using standard procedures. All fertilization and irrigation applications were conducted as (Sharif et al., 2004; Hussaini et al., 2008; Rezvantalab et al., 2008). The concentrations of $\mathrm{Zn}, \mathrm{Fe}, \mathrm{Mn}$ and $\mathrm{Cu}$ in the digested solutions were determined by inductively coupled plasma atomic emission spectroscopy (ICP-AES, OPTIMA 3300 DV, Perkin-Elmer, USA). IPE556 grain and IPE883 straw (Wageningen University, The Netherlands) were used as reference materials (Hussaini et al., 2008).

Three different irrigation methods were applied in the research, and the irrigation was the same in the both seasons of 2015 and 2016. Details of irrigation applications are given below (Table 3).

Table 3. Details of different irrigation application have been shown

\begin{tabular}{|c|c|c|c|c|c|c|}
\hline Years & \multicolumn{2}{|c|}{ 1.st irrigation application } & \multicolumn{2}{|c|}{ 2nd irrigation application } & \multicolumn{2}{|c|}{ 3rd irrigation application } \\
\hline \multirow{6}{*}{$\begin{array}{c}2015^{*} \\
2016\end{array}$} & 1st at three leaf stage & $125 \mathrm{~mm}$ & 1st at three leaf stage & $125 \mathrm{~mm}$ & 1st at three leaf stage & $125 \mathrm{~mm}$ \\
\hline & 2nd at ninth-leaf stage & $125 \mathrm{~mm}$ & 2nd at ninth-leaf stage & $125 \mathrm{~mm}$ & 2nd at ninth-leaf stage & $125 \mathrm{~mm}$ \\
\hline & 3rd at tasseling stage & $125 \mathrm{~mm}$ & 3rd at tasseling stage & $125 \mathrm{~mm}$ & 3rd at tasseling stage & $125 \mathrm{~mm}$ \\
\hline & 4th at milking stage & $125 \mathrm{~mm}$ & 4th at milking stage & $125 \mathrm{~mm}$ & \multirow{3}{*}{$\begin{array}{l}\text { 4th at milking stage } \\
5 \text { th at dough stage } \\
6 \text { th at dough stage }\end{array}$} & \multirow{3}{*}{$\begin{array}{l}125 \mathrm{~mm} \\
125 \mathrm{~mm} \\
125 \mathrm{~mm}\end{array}$} \\
\hline & & & 5th at dough stage & $125 \mathrm{~mm}$ & & \\
\hline & & & & & & \\
\hline Total & \multicolumn{2}{|l|}{$500 \mathrm{~mm}$} & \multicolumn{2}{|l|}{$625 \mathrm{~mm}$} & \multicolumn{2}{|l|}{$750 \mathrm{~mm}$} \\
\hline
\end{tabular}

* Irrigation was used the same for both (2015 and 2016) seasons

The sowing was made $5 \mathrm{~cm}$ depth, the eight seeds counted for per square meter and the separate of between two rows calculated $70 \mathrm{~cm}$ and between two plant on bed 20 $\mathrm{cm}$. The first-year sowing was down on 15th of June 2014 with trial plantation and harvest was made on 5 November 2014. The second-year sowing was made on 13 June 2015; the harvest was made on 10 November 2015. On the other hand, chemical application and hoeing were made against weeds during the growing season in the trial plots. Any chemical drugs were not used during these two years, because there was no shown disease in the trials.

Observations and measurements in each plot were calculated by taking the mean of 10 randomly selected plants. Observations and measurements were obtained as suggested by Turgut (2003).

The effect of treatments (Irrigation schedules and sources of manure) on maize were analyzed using the analysis of variance procedures for a randomized complete block design with the SAS (1998) statistical package. When the F-value of the ANOVA was significant at the $\mathrm{P}<0.05$ level of probability. The means related with nutrient content, yield and yield components in maize were evaluated with Duncan's Multiple Range Test statistical analysis.

\section{Results}

Regarding maize grown under different fertilizer and irrigation treatments, results in Table 4 indicated that all the studied characteristics were significantly affected by irrigation treatments over the two growing seasons.

The highest plant height, according to the sources of manure, were obtained from M1 with $226.9 \mathrm{~cm}$ and $215.7 \mathrm{~cm}$ for 2014 and 2015, respectively. But the difference with 
M2 (chicken manure) was not statistically significant in both years. The lowest plant heights were obtained from control plots with $205.4 \mathrm{~cm}$ and $200.3 \mathrm{~cm}$ in 2014 and 2015 , respectively. According to the irrigation schedules, the plant height ranged between 199.4 and $239.7 \mathrm{~cm}$ in the first year, and 190.5 and $239.9 \mathrm{~cm}$ in the second.

In terms of first cob height, the highest values were obtained from M1 with $89.7 \mathrm{~cm}$ and $91.8 \mathrm{~cm}$ for both years, whereas the lowest first cob height was obtained control plots (M0). On the other hand, the difference among M, M2 and M3 was found to be statistically insignificant in the first year. According to the irrigation schedules the first cob height ranged between 83.2 and $90.7 \mathrm{~cm}$ in 2014, and 80.2 and $90.4 \mathrm{~cm}$ in 2015 . The lowest first cob heights were observed in the I1 application, whereas the highest values were obtained from the I3 application (Table 4).

Table 4. Effect of irrigation schedules and sources of manure on yield and yield components of maize and Duncan groups (2014-2015)

\begin{tabular}{|c|c|c|c|c|c|c|c|c|}
\hline \multirow[t]{2}{*}{ Characters } & \multirow[t]{2}{*}{ Years } & \multicolumn{4}{|c|}{ Sources of manure } & \multicolumn{3}{|c|}{ Irrigation schedules } \\
\hline & & M0 & M1 & M2 & M3 & I1 & I2 & I3 \\
\hline \multirow{2}{*}{$\begin{array}{l}\text { Plant height } \\
(\mathrm{cm})\end{array}$} & 2014 & $205.1 \mathrm{c}$ & $226.9 \mathrm{a}$ & $225.7 \mathrm{a}$ & $219.6 \mathrm{~b}$ & $199.4 \mathrm{c}$ & $218.9 \mathrm{~b}$ & $239.7 \mathrm{a}$ \\
\hline & 2015 & $200.3 \mathrm{c}$ & $215.7 \mathrm{a}$ & $214.2 \mathrm{a}$ & $209.8 \mathrm{~b}$ & $190.5 \mathrm{c}$ & $199.5 \mathrm{~b}$ & $239.9 \mathrm{a}$ \\
\hline \multirow{2}{*}{$\begin{array}{l}\text { First cob height } \\
(\mathrm{cm})\end{array}$} & 2014 & $83.4 \mathrm{~b}$ & $89.7 \mathrm{a}$ & $88.9 \mathrm{a}$ & $88.3 \mathrm{a}$ & $83.2 \mathrm{c}$ & $87.7 \mathrm{~b}$ & $90.7 \mathrm{a}$ \\
\hline & 2015 & $84.9 \mathrm{c}$ & $91.8 \mathrm{a}$ & $87.9 \mathrm{bc}$ & $90.4 \mathrm{ab}$ & $80.2 \mathrm{~b}$ & $85.7 \mathrm{a}$ & $90.4 \mathrm{a}$ \\
\hline \multirow{2}{*}{ Cob height $(\mathrm{cm})$} & 2014 & $17.7 \mathrm{~d}$ & $19.1 \mathrm{c}$ & $20.9 \mathrm{a}$ & $20.3 \mathrm{~b}$ & $17.2 \mathrm{c}$ & $19.3 \mathrm{~b}$ & $22.1 \mathrm{a}$ \\
\hline & 2015 & $18.1 \mathrm{c}$ & $19.5 \mathrm{~b}$ & $21.3 \mathrm{a}$ & $19.9 \mathrm{~b}$ & $17.8 \mathrm{c}$ & $18.8 \mathrm{~b}$ & $22.6 \mathrm{a}$ \\
\hline \multirow{2}{*}{$\begin{array}{l}\text { No. of } \\
\text { grains/cob } \\
\text { (number) }\end{array}$} & 2014 & $323.3 \mathrm{c}$ & $394.1 \mathrm{~b}$ & $419.6 \mathrm{ab}$ & $431.3 \mathrm{a}$ & $289.3 \mathrm{c}$ & $347.6 \mathrm{~b}$ & $546.1 \mathrm{a}$ \\
\hline & 2015 & $375.3 \mathrm{c}$ & $390.2 \mathrm{c}$ & $468.7 \mathrm{a}$ & $448.1 \mathrm{~b}$ & $371.7 \mathrm{c}$ & $399.8 \mathrm{~b}$ & $490.2 \mathrm{a}$ \\
\hline \multirow{2}{*}{$\begin{array}{l}\text { Grain yield of } \\
\text { cob }(\mathrm{g})\end{array}$} & 2014 & $24.4 \mathrm{~d}$ & $28.3 \mathrm{c}$ & $36.1 \mathrm{a}$ & $33.0 \mathrm{~b}$ & $24.5 \mathrm{c}$ & $27.1 \mathrm{~b}$ & $39.7 \mathrm{a}$ \\
\hline & 2015 & $31.8 \mathrm{~b}$ & $38.7 \mathrm{a}$ & $38.2 \mathrm{a}$ & $37.6 \mathrm{a}$ & $29.4 \mathrm{c}$ & $36.5 \mathrm{~b}$ & $43.7 \mathrm{a}$ \\
\hline \multirow{2}{*}{$\begin{array}{l}\text { 1000-seed } \\
\text { weight }(\mathrm{g})\end{array}$} & 2014 & $121.1 \mathrm{~b}$ & $124.0 \mathrm{~b}$ & $134.8 \mathrm{a}$ & $132.9 \mathrm{a}$ & $118.9 \mathrm{c}$ & $126.9 \mathrm{~b}$ & $138.7 \mathrm{a}$ \\
\hline & 2015 & $135.7 \mathrm{~b}$ & $137.9 \mathrm{ab}$ & $143.7 \mathrm{ab}$ & $145.1 \mathrm{a}$ & $135.5 \mathrm{~b}$ & $139.4 \mathrm{ab}$ & $148.9 \mathrm{a}$ \\
\hline \multirow{2}{*}{$\begin{array}{c}\text { Grain yield }(\mathrm{kg} \\
\left.\mathrm{ha}^{-1}\right)\end{array}$} & 2014 & $6362 \mathrm{~d}$ & $7833 \mathrm{c}$ & $9646 \mathrm{a}$ & $8841 \mathrm{~b}$ & $6386 \mathrm{c}$ & $7448 \mathrm{~b}$ & $10678 \mathrm{a}$ \\
\hline & 2015 & Çö & $11243 \mathrm{a}$ & $11019 \mathrm{a}$ & $9429 \mathrm{~b}$ & $7575 \mathrm{~b}$ & $9056 \mathrm{~b}$ & $12133 \mathrm{a}$ \\
\hline \multirow{2}{*}{ Hectoliter (kg) } & 2014 & $69.8 \mathrm{c}$ & $71.1 \mathrm{~b}$ & $73.9 \mathrm{a}$ & $72.1 \mathrm{~b}$ & $69.4 \mathrm{~b}$ & $73.1 \mathrm{a}$ & $72.6 \mathrm{a}$ \\
\hline & 2015 & $69.9 \mathrm{~d}$ & $71.4 \mathrm{c}$ & $72.8 \mathrm{a}$ & $72.1 \mathrm{~b}$ & $70.4 \mathrm{c}$ & $71.7 \mathrm{~b}$ & $72.7 \mathrm{a}$ \\
\hline \multirow{2}{*}{$\begin{array}{c}\text { Seed oil content } \\
(\%)\end{array}$} & 2014 & $3.50 \mathrm{c}$ & $4.05 \mathrm{a}$ & $3.89 \mathrm{ab}$ & $3.84 \mathrm{~b}$ & $3.60 \mathrm{~b}$ & $3.73 \mathrm{~b}$ & $4.13 \mathrm{a}$ \\
\hline & 2015 & $3.57 \mathrm{~d}$ & $4.32 \mathrm{a}$ & $3.94 \mathrm{~b}$ & $3.72 \mathrm{c}$ & $3.58 \mathrm{c}$ & $3.91 \mathrm{~b}$ & $4.17 \mathrm{a}$ \\
\hline \multirow{2}{*}{$\begin{array}{l}\text { Seed protein } \\
\text { ratio }(\%)\end{array}$} & 2014 & $8.9 \mathrm{c}$ & $10.4 \mathrm{~b}$ & $10.9 \mathrm{a}$ & $10.3 \mathrm{~b}$ & $9.6 \mathrm{~b}$ & $9.9 \mathrm{~b}$ & $10.8 \mathrm{a}$ \\
\hline & 2015 & $9.01 \mathrm{~b}$ & $9.50 \mathrm{~b}$ & $10.6 \mathrm{a}$ & $9.91 \mathrm{ab}$ & $9.30 \mathrm{~b}$ & $9.46 \mathrm{~b}$ & $10.51 \mathrm{a}$ \\
\hline
\end{tabular}

I1: Four irrigations (1st at three leaf stage, 2nd at ninth-leaf stage, 3rd at tasseling stage, 4th at milking stage), I2: Five irrigations (1st at fourth leaf stage, 2nd at ninth leaf stage, 3rd at tasseling, 4th at milking stage, 5th at dough stage ) and I3:Six irrigations (1st at third leaf stage, 2nd at ninth leaf stage, 3rd at tasseling, 4th at blister stage, 5th at milking stage, 6th at dough stage) and four manure (M0:control, M1: 180-80 kg N-P $\mathrm{P}_{5}-\mathrm{ha}^{-1}$, M2: Chicken manure $15 \mathrm{t} \mathrm{ha}^{-1}$ and M3: Farmyard manure $\left.15 \mathrm{tha}^{-1}\right)$

The highest cob lengths according to the sources of manure were obtained from M2 with $20.9 \mathrm{~cm}$ and $21.3 \mathrm{~cm}$ for the first and second years, respectively. The lowest cob lengths were obtained from control plots (M0) with 17.7 and $18.1 \mathrm{~cm}$ for 2014 and 2015 , respectively. The highest cob lengths for irrigation were obtained from I3 with 22.1 and $22.6 \mathrm{~cm}$ in the first year and the second, respectively, while the lowest values were obtained from I1 for both years.

The highest number of grains/cob, according to the sources of manure, was obtained from M3 with 431.3 grains/cob in 2015. The highest number of grains/cob was obtained from M2 with 468.7 grains/cob in 2015. The lowest grains/cob were obtained from 
control plots in both years but the difference between M0 and M1 was not statistically significant in the second year. In terms of irrigation schedule, the number of grains/cob ranged between 289.3 and 546.1 grains/cob in the first year, and 371.7 and 490.2 grains/cob in the second year.

In terms of grain yield of cob, while the highest value was collected from M2 with $36.1 \mathrm{~g}$, the lowest value was obtained from $24.4 \mathrm{~g}$ for the first year. Whereas, the highest value was obtained from M1 with $38.7 \mathrm{~g}$ but the difference among M1, M2 and M3 was found to be statistically insignificant in the second year. According to the irrigation schedules, grain yield of cob ranged between 24.5 and $39.7 \mathrm{~g}$ in 2014, and 29.4 and 43.7 $\mathrm{g}$ in 2015. The lowest values were collected from the I1 application, whereas the highest values were obtained from the I3 application (Table 4).

Significant results of both factors under study during both years of experimentation were found. According to the source of manure, the highest 1000 seed weight was obtained from M2 with $134.8 \mathrm{~g}$ in the first year, while the highest 1000 seed weight was collected M3 with $145.1 \mathrm{~g}$ in the second year. The lowest values were obtained from control plots in both years. In terms of irrigation schedule, the highest 1000 seed weights were obtained from I3 with 138.7 and $148.9 \mathrm{~g}$ for years, whereas the lowest values were obtained from the I1 application with 118.9 and $135.5 \mathrm{~g}$ for the first year and the second, respectively.

In terms of grain yield, the highest values were obtained from M2 with 9646 and $11019 \mathrm{~kg} \mathrm{ha}^{-1}$ for 2014 and 2015, while the lowest values were obtained from M0 with 6363 and $6662 \mathrm{~kg} \mathrm{ha}^{-1}$ for both years, respectively. But the difference between M1 and M2 was not statistically significant in the second year. These finding are also supported by (Seker and Ersoy, 2005). According to the irrigation schedules, the grain yield ranged from 6386 to $10678 \mathrm{hg} / \mathrm{ha}$ in the first year, and from 7575 to $12133 \mathrm{~kg} \mathrm{ha}^{-1}$ in 2015. The lowest seed yield was collected from the I1 application, whereas the highest values were obtained from the $\mathrm{I} 3$ application (Table 3).

The highest hectoliter weight was obtained from M2 with 73.9 and $72.8 \mathrm{~kg}$ for the first year and the second, whereas the lowest hectoliter weight were observed from control plots both years. In terms of irrigation schedule, the highest hectoliter weights were obtained from I2 with $73.1 \mathrm{~kg}$ in the first year, I3 with $72.7 \mathrm{~kg}$ in 2015 , the lowest values were obtained from I1 application with 69.4 and $70.4 \mathrm{~kg}$ for the first year and the second, respectively. But the difference between I 2 and I3 was statistically insignificant in 2014.

The highest grain oil contents were reached from M1 with 4.05-4.32\%, the lowest values were obtained from M0 application with 3.50-3.57\% for 2014 and 2015, respectively. According to the irrigation schedules the seed oil content ranged between 3.60 and $4.13 \%$ in 2014 , and 3.58 and $4.17 \%$ in 2015 . The lowest seed oil contents were obtained from the I1 application, whereas the highest values were obtained from the I3 application (Table 5). In terms of seed protein ratio, the highest values were obtained from M2 with 10.9 and $10.6 \%$ for the first and the second years, the lowest values were obtained from control plots with 8.9 and $9.01 \%$ for both years, respectively. The highest seed protein ratio for irrigation schedule were obtained from I3 with 10.8 and $10.51 \%$ in 2014 and 2015, respectively, while the lowest values were obtained from I1 but the difference between I1 and I2 was statistically insignificant for both of the years.

The results on the nutrient contents of maize, based on the application of different manures and irrigation schedules, are showed in Table 4. When the effect of irrigation schedules and sources of manure on nutrient contents of maize seed, the highest $\mathrm{K}$ 
values were obtained from the M2 application in both of the years but there among M1, M2 and M3 was not statistically significant in the first year. When potassium is examined in terms of irrigation schedule while the highest values obtained from I3, the lowest values obtained from I1, but the difference between I 2 and I3 was statistically insignificant in the second year.

The highest $\mathrm{Na}, \mathrm{Mg}$ and $\mathrm{Ca}$ values were obtained from $\mathrm{M} 2$ application, while the lowest values were obtained from M0 application in 2014 and 2015. According to the irrigation schedule, the I1application gave the lowest value while the I3 gave the highest value (Table 5).

Table 5. Effect of irrigation schedules and sources of manure on nutrient contents of maize seed and Duncan groups (2014-2015)

\begin{tabular}{c|c|c|c|c|c|c|c|c}
\hline \multirow{2}{*}{ Characters } & Years & \multicolumn{4}{|c|}{ Sources of manure } & \multicolumn{2}{c}{ Irrigation schedules } \\
\cline { 2 - 8 } & & M0 & M1 & M2 & M3 & I1 & I2 & I3 \\
\hline \multirow{2}{*}{$\mathrm{K}(\mathrm{ppm})$} & 2014 & $2468.7 \mathrm{~b}$ & $2757.1 \mathrm{a}$ & $2926.5 \mathrm{a}$ & $2814.1 \mathrm{a}$ & $2121.2 \mathrm{c}$ & $2807.5 \mathrm{~b}$ & $3296.0 \mathrm{a}$ \\
\cline { 2 - 9 } & 2015 & $2489.4 \mathrm{c}$ & $3018.3 \mathrm{~b}$ & $3472.6 \mathrm{a}$ & $3084.5 \mathrm{~b}$ & $2576.8 \mathrm{~b}$ & $3136.7 \mathrm{a}$ & $3335.1 \mathrm{a}$ \\
\hline \multirow{2}{*}{$\mathrm{Na}(\mathrm{ppm})$} & 2014 & $18.31 \mathrm{c}$ & $27.72 \mathrm{~b}$ & $33.74 \mathrm{a}$ & $27.85 \mathrm{~b}$ & $13.30 \mathrm{c}$ & $27.18 \mathrm{~b}$ & $40.23 \mathrm{a}$ \\
\cline { 2 - 9 } & 2015 & $27.02 \mathrm{c}$ & $32.86 \mathrm{~b}$ & $36.46 \mathrm{a}$ & $32.40 \mathrm{~b}$ & $24.70 \mathrm{c}$ & $30.80 \mathrm{~b}$ & $41.06 \mathrm{a}$ \\
\hline \multirow{2}{*}{$\mathrm{Mg}(\mathrm{ppm})$} & 2014 & $667.7 \mathrm{~b}$ & $675.5 \mathrm{~b}$ & $717.7 \mathrm{a}$ & $663.2 \mathrm{~b}$ & $664.0 \mathrm{c}$ & $686.3 \mathrm{~b}$ & $712.2 \mathrm{a}$ \\
\cline { 2 - 9 } & 2015 & $713.8 \mathrm{c}$ & $740.1 \mathrm{~b}$ & $763.1 \mathrm{a}$ & $742.3 \mathrm{~b}$ & $725.6 \mathrm{~b}$ & $734.5 \mathrm{~b}$ & $759.3 \mathrm{a}$ \\
\hline \multirow{2}{*}{$\mathrm{Ca}(\mathrm{ppm})$} & 2014 & $47.55 \mathrm{~b}$ & $56.68 \mathrm{ab}$ & $61.72 \mathrm{a}$ & $54.90 \mathrm{ab}$ & $46.10 \mathrm{~b}$ & $56.64 \mathrm{ab}$ & $62.90 \mathrm{a}$ \\
\cline { 2 - 9 } & 2015 & $35.40 \mathrm{~d}$ & $40.88 \mathrm{c}$ & $46.52 \mathrm{a}$ & $43.40 \mathrm{~b}$ & $36.00 \mathrm{c}$ & $41.19 \mathrm{~b}$ & $47.45 \mathrm{a}$ \\
\hline \multirow{2}{*}{$\mathrm{Fe}(\mathrm{ppm})$} & 2014 & $12.11 \mathrm{c}$ & $14.24 \mathrm{~b}$ & $15.41 \mathrm{a}$ & $14.37 \mathrm{~b}$ & $12.51 \mathrm{c}$ & $14.20 \mathrm{~b}$ & $15.39 \mathrm{a}$ \\
\cline { 2 - 9 } $\mathrm{Cu}(\mathrm{ppm})$ & 2015 & $12.57 \mathrm{c}$ & $16.42 \mathrm{~b}$ & $18.07 \mathrm{a}$ & $15.72 \mathrm{~b}$ & $14.25 \mathrm{~b}$ & $16.15 \mathrm{a}$ & $16.69 \mathrm{a}$ \\
\cline { 2 - 9 } & 2014 & $2.916 \mathrm{~d}$ & $3.223 \mathrm{c}$ & $4.330 \mathrm{a}$ & $3.897 \mathrm{~b}$ & $3.141 \mathrm{c}$ & $3.430 \mathrm{~b}$ & $4.204 \mathrm{a}$ \\
\hline \multirow{2}{*}{$\mathrm{Zn}(\mathrm{ppm})$} & 2015 & $3.970 \mathrm{c}$ & $5.858 \mathrm{a}$ & $4.858 \mathrm{~b}$ & $4.634 \mathrm{~b}$ & $4.406 \mathrm{~b}$ & $4.791 \mathrm{ab}$ & $5.293 \mathrm{a}$ \\
\cline { 2 - 9 } & 2014 & $13.45 \mathrm{~d}$ & $14.70 \mathrm{c}$ & $17.37 \mathrm{a}$ & $16.05 \mathrm{~b}$ & $14.80 \mathrm{~b}$ & $15.07 \mathrm{~b}$ & $16.30 \mathrm{a}$ \\
\hline \multirow{2}{*}{$\mathrm{Mn}(\mathrm{ppm})$} & 2014 & $14.11 \mathrm{~b}$ & $14.88 \mathrm{~b}$ & $16.72 \mathrm{a}$ & $14.50 \mathrm{~b}$ & $13.10 \mathrm{c}$ & $15.37 \mathrm{~b}$ & $16.83 \mathrm{a}$ \\
\cline { 2 - 8 } & 2015 & $2.954 \mathrm{c}$ & $5.755 \mathrm{~b}$ & $6.258 \mathrm{a}$ & $6.191 \mathrm{~b}$ & $5.524 \mathrm{c}$ & $5.74 \mathrm{~b}$ & $6.369 \mathrm{a}$ \\
\hline \multirow{2}{*}{$\mathrm{Ni}(\mathrm{ppm})$} & 2014 & $0.316 \mathrm{~b}$ & $0.394 \mathrm{ab}$ & $0.423 \mathrm{a}$ & $0.418 \mathrm{a}$ & $0.333 \mathrm{~ns}$ & $0.405 \mathrm{~ns}$ & $0.425 \mathrm{~ns}$ \\
\cline { 2 - 8 } & 2015 & $0.460 \mathrm{~b}$ & $0.484 \mathrm{~b}$ & $0.560 \mathrm{a}$ & $0.508 \mathrm{ab}$ & $0.511 \mathrm{a}$ & $0.466 \mathrm{~b}$ & $0.531 \mathrm{a}$ \\
\hline \multirow{2}{*}{$\mathrm{Pb}(\mathrm{ppm})$} & 2014 & $0.367 \mathrm{~ns}$ & $0.432 \mathrm{~ns}$ & $0.350 \mathrm{~ns}$ & $0.412 \mathrm{~ns}$ & $0.319 \mathrm{~b}$ & $0.372 \mathrm{~b}$ & $0.480 \mathrm{a}$ \\
\cline { 2 - 8 } & 2015 & $0.405 \mathrm{c}$ & $0.577 \mathrm{~b}$ & $0.638 \mathrm{a}$ & $0.546 \mathrm{~b}$ & $0.430 \mathrm{c}$ & $0.571 \mathrm{~b}$ & $0.657 \mathrm{a}$ \\
\hline
\end{tabular}

I1: Four irrigations (1st at three leaf stage, 2nd at ninth-leaf stage, 3rd at tasseling stage, 4th at milking stage), I2: Five irrigations (1st at fourth leaf stage, 2nd at ninth leaf stage, 3rd at tasseling, 4th at milking stage, 5th at dough stage ) and I3: Six irrigations (1st at third leaf stage, 2nd at ninth leaf stage, 3rd at tasseling, 4th at blister stage, 5th at milking stage, 6th at dough stage) and four manure (M0: control, M1:180-80 kg N-P $\mathrm{O}_{2} \mathrm{O}^{-} \mathrm{ha}^{-1}$, M2:Chicken manure $15 \mathrm{tha}^{-1}$ and M3:Farmyard manure $15 \mathrm{t} \mathrm{ha}^{-1}$ )

In terms of $\mathrm{Fe}$ contents, the highest values were obtained from M2 application, the lowest values were obtained from the M0 application in both of the years. When Fe is examined in terms of irrigation schedule, the highest values obtained from I3, while the lowest values obtained from I1, but the difference between I 2 and I3 was statistically insignificant in the second year.

When evaluated in terms of copper contents, the highest $\mathrm{Cu}$ content was obtained from M2 in the first year, M1 in the second. The lowest values were obtained from M0 in both years. In addition, the $\mathrm{I} 3$ application has the highest $\mathrm{Cu}$ content, whereas the I1 application has the lowest content both years. But the difference between I1 and I 2 in 2014 and among I1, I2 and I3 in 2015 was not statistically significant.

The highest $\mathrm{Zn}, \mathrm{Mn}$, and Ni contents were obtained from M2 application, whereas the lowest values were obtained from the M0 application in 2014 and 2015. But the 
difference between M2 and M3 was statistically insignificant for Ni content in the first year. According to the irrigation schedule the highest values were obtained from $\mathrm{I} 3$, the lowest values were obtained from I1 except $\mathrm{Ni}$ content both years. Ni content was found to be insignificant in 2014 .

According to the source of manure, $\mathrm{Pb}$ content was found to be insignificant in the first year, while the highest value was obtained from M2, the lowest value was obtained from M0 in the second year. In terms of irrigation schedule the highest values were obtained from the I3 application, the lowest values were obtained from the I1 application. But the difference between I1 and I2 was not statistically significant.

There was a significant interaction between irrigation schedules and different manure sources during both years. In Table 6 I3 M2 (the first year: six irrigations and chicken manure) and I3 M1 (the second year: six irrigations and farmyard manure) interaction produced maximum grain yield (1348 kg ha-1 in 2014 and $1495 \mathrm{~kg} \mathrm{ha}^{-1}$ in 2015).

Table 6. Interaction between irrigation schedules and different manure sources affecting grain yield $\left(\mathrm{kg} \mathrm{ha}^{-1}\right)$ during 2014 and 2015

\begin{tabular}{c|c|c|c|c|c}
\hline \multirow{2}{*}{} & \multirow{2}{*}{ Irrigation schedules } & \multicolumn{4}{|c}{ Sources of manure } \\
\cline { 3 - 5 } & & M0 & M1 & M2 & M3 \\
\hline \multirow{3}{*}{2014} & I1 & $5665 \mathrm{i}$ & $6309 \mathrm{~h}$ & $6833 \mathrm{fg}$ & $6736 \mathrm{fgh}$ \\
& $\mathbf{I}$ & $6402 \mathrm{gh}$ & $6857 \mathrm{fg}$ & $8618 \mathrm{~d}$ & $7913 \mathrm{e}$ \\
& $\mathbf{I 3}$ & $7020 \mathrm{f}$ & $1033 \mathrm{c}$ & $1348 \mathrm{a}$ & $1187 \mathrm{~b}$ \\
\hline \multirow{2}{*}{2015} & $\mathbf{I}$ & $5674 \mathrm{~g}$ & $8192 \mathrm{ef}$ & $8772 \mathrm{de}$ & $7664 \mathrm{ef}$ \\
& $\mathbf{I 2}$ & $6286 \mathrm{fg}$ & $1057 \mathrm{~cd}$ & $1082 \mathrm{c}$ & $8538 \mathrm{e}$ \\
& $\mathbf{I 3}$ & $8025 \mathrm{ef}$ & $1495 \mathrm{a}$ & $1346 \mathrm{ab}$ & $1208 \mathrm{bc}$ \\
\hline
\end{tabular}

\section{Discussion}

Each year was separately evaluated since there were significant differences between both years, as found from combined analysis. Maize yield and its components tend to be higher in 2015 growing season, compared with 2014 growing season. This could be attributed to favorable climatic conditions that were prevailing during the 2015 growing season. The lowest plant heights were obtained from the I1 application, whereas the highest values were obtained from the I3 application (Table 4). These results are similar to the findings of Randhawa et al. (2012), and El-Gizawi and Nasser (2005), who found taller plants by increasing irrigation interval. While the minimum plant height was obtained in control treatment. These results are inline as the results of Qasim et al. (2001), who reported an increase in plant height with farmyard manure application due to more availability and uptake of nutrients. Increasing scarcity and greater competition for use of freshwater resources will force irrigated agriculture to be more efficient in use of available supplies. Significant difference was found among the irrigation treatments and different manure sources on the production of first cob height and cob length. The highest values were obtained for the I3 irrigation application and the M2 fertilization. Similar effects were observed by Abera et al. (2013) and Majid et al. (2017). Rezvantalab et al. (2008) also reported higher number of grains cob-1 with application of farmyard manure and mineral fertilizers. While the highest values were obtained from I3, the lowest values were obtained from I1. Confirmatory results regarding number of grains cob-1 were given by El-Tantawy et al. (2007), who reported significant differences among different irrigation schedules. According to the irrigation schedules, grain yield of cob ranged between 24.5 and $39.7 \mathrm{~g}$ in 2014, and 29.4 and 43.7 
$\mathrm{g}$ in 2015. The lowest values were collected from the I1 application, whereas the highest values were obtained from the I3 application (Table 4). These data confirm that of ElTantawy et al. (2007) and Majid et al. (2017), who reported significant response of supplementary irrigation on grain weight cob-1. The highest 1000 grain weight was produced with the I3 irrigation treatment whereas the minimum weight of 1000-grain was produced by the control treatment. Significant results of both factors under the study during both years of experimentation were found. In case of plant nutrition treatments, the highest 1000-grain weight was noted in treatment chicken manure $15 \mathrm{t}$ $\mathrm{ha}^{-1}$ (M2) as compared to all other integrated plant nutrition treatments in 2014. The same trend was observed during 2015. The increase in 1000-grain weight might be due to integrated use of farmyard manure and I3. Reports supporting the present results have appeared in the literature by Sharif et al. (2004) and Kashiani et al. (2011). The levels of irrigation and different manure sources remarkably influenced the grain yield in cultivar Limagrain Helen. Minimum grain yield counted from the treatment I1 M0, and it differed statistically from other treatments applications. The water stress (deficit water) remarkably influenced productivity and quality in maize (Barutcular et al., 2016; El Sabagh et al., 2017). However, water availability is usually the most important crop production factor limiting yield and yield traits of maize. These facts are comparable with the study of (Zhang et al., 2007) who obtained higher yield with the increase in number of irrigations. These results are similar to the findings of (Randhawa et al., 2012). The highest grain oil contents were reached from M1 with 4.05-4.32\%, the lowest values were obtained from the M0 application with $3.50-3.57 \%$ for 2014 and 2015, respectively. According to the irrigation schedules, the seed oil content ranged between $3.60-4.13 \%$ in 2014 and $3.58-4.17 \%$ in the second year. The lowest seed oil contents were obtained from the I1 application, whereas the highest values were obtained from the I3 application. These results were in agreement with what was obtained by Yalçın et al. (2006). Grain analysis has been used to reveal the deficiency, adequacy or excessiveness status of various nutrient elements in a soil-plant system. Chicken manure application significantly increased the concentrations of $\mathrm{K}, \mathrm{Ca}, \mathrm{Cu}, \mathrm{Fe}$, $\mathrm{Mn}, \mathrm{Zn}, \mathrm{Ni}$ and $\mathrm{Mg}$ in maize seed. Application of chicken dunk organic fertilizer not only capable to increase sweet corn production, but also had positive impacts in term of improvement of soil physical, chemical and biological properties. Improvement of soil physical properties is achieved because organic matter (organic fertilizer) functions as adhesive of loose soil particles or aggregate stabilizer compound (Gonzales et al., 2002; Margaretha et al., 2014). The highest $\mathrm{Na}, \mathrm{Mg}$ and Ca values were obtained from the M2 application. The lowest values were obtained from the M0 application in the first year and the second. According to the irrigation schedule, the I1 application gave the lowest value while I3 gave the highest. Similar effects were observed by Hussaini et al. (2008).

\section{Conclusions}

The effects on all the characteristics researched for different sources of manure and irrigation schedules were statistically significant for 2014 and 2015. The results of our work indicated that the highest plant yield for maize planted in both growing seasons of 2014 and 2015 was obtained when the plants were irrigated six times. On the basis of this two-year study, it is concluded that in order to obtain higher grain yield of hybrid maize under agro ecological conditions of Mardin/Turkey, the crop should be irrigated six times and fertilized with organic manures ( $15 \mathrm{t}$ chicken manure ha $\left.{ }^{-1}\right)$. While the 
highest grain yield per area was obtained from the third irrigation schedule and chicken manure in 2014, the highest value was obtained from the third irrigation schedule and standard fertilizer with $14959 \mathrm{~kg} \mathrm{ha}^{-1}$ and the third irrigation schedule and chicken manure with $13463 \mathrm{~kg} \mathrm{ha}^{-1}$ in 2015. Chicken manure application significantly increased the concentrations of $\mathrm{K}, \mathrm{Ca}, \mathrm{Cu}, \mathrm{Fe}, \mathrm{Mn}, \mathrm{Zn}, \mathrm{Ni}$ and $\mathrm{Mg}$ in maize seed. The results revealed that increase in soil moisture and mineral contents leads to increase in plant growth promotion and biomass production.

Acknowledgements. This study is a research artcile and supported as a project number MAU-BAP-2015MYO-15 by M.A. University Research Fund.

\section{REFERENCES}

[1] Aberaa, G., Wolde, E., Bakken, L. R. (2013): Effect of organic residue amendments and soil moisture on $\mathrm{N}$ mineralization, maize (Zea mays L.) dry biomass and nutrient concentration. - Archives of Agronomy and Soil Science 59: 1263-1277.

[2] Abrecht, D. G., Carberry, P. S. (1993): The influence of water deficit prior to tassel initiation on maize growth, development and yield. - Field Crop Research 31(1-2): 55-69.

[3] Barutçular, C., Dizlek, H., EL-Sabagh, A., Sahin, T., EL-Sabagh, M., Islam, M. S. (2016): Nutritional quality of maize in response to drought stress during grain-filling stages in mediterranean climate condition. - Journal of Experimental Biology and Agricultural Sciences 4(6): 644-652.

[4] Bouyoucos, G. S. (1951): Recalibration of the hydrometer methods for making mechanical analysis of soil. - Agronomy J. 43: 434-438.

[5] DeJager, A., Onduru, D., Van Wijk, M. S., Vlaming, J., Gachini, G. N. (2001): Assessing sustainability of low external input farm management systems with the nutrient monitoring approach A case study in Kenya. - Agric Syst 69: 99-118.

[6] Eghball, B., Power, J. F. (1999): Phosphorus and nitrogen-based manure and compost applications corn production and soil phosphorus. - Soil Sci Soc Am J. 54: 1161-1165.

[7] El-Gizawi, N. K. (2005): Effect of irrigation intervals, nitrogen rates and spraying with zinc on yield and agronomic efficiency of nitrogen in maize. - Ann. Agricul. Sci. Moshtohor 43: 1007-20.

[8] EL Sabagh, A., Barutçular, C., Islam, M. S. (2017): Relationships between stomatal conductance and yield under deficit irrigation in maize (Zea mays L.). - Journal of Experimental Biology and Agricultural Sciences 5: 15-21. DOI 10.18006/2017.5 (1).014.021.

[9] El-Tantawy, M. M., Ouda, S. A., Khalil, F. A. (2007): Irrigation scheduling for maize grown under middle Egypt conditions. - Res. J. Agri. Biol. Sci. 3: 456-62.

[10] FAO (2017): http://www.fao.org/statistics/en/

[11] Gilley, J. E., Risse, M. (2000): Runoff and soil loss as affected by the application of manure. - Trans ASAE 43: 1583-1588.

[12] Gilley, J. E., Eghball, B. (2002): Residual effects of compost and fertilizer applications on nutrients in runoff. - Trans ASAE 45: 1905-1910.

[13] Gonzales, R. F., Cooperband, L. R. (2002): Compost. Sci. Util. 10: 226.

[14] Gordon, W. B., Raney, R. J., Stone, L. R. (1995): Irrigation management practice for corn production in north central Kansas. - J. Soil Water Conserv 50(4): 395-398.

[15] Haynes, R. J., Naidu, R. (1998): Influence of lime, fertilizer, and manure applications and soil organic matter content and soil physical conditions - A review. - Nutr Cycl Agroecosys 51: 123-137. 
[16] Hussaini, M. A., Ogunlela, V. B., Ramalan, A. A., Falaki, A. M. (2008): Mineral Composition of Dry Season Maize (Zea mays L.) in Response to Varying Levels of Nitrogen, Phosphorus and Irrigation at Kadawa, Nigeria. - World Journal of Agricultural Sciences 4(6): 775-780.

[17] Jackson, M. L. (1962): Soil Chemical Analysis. - Engle Wood Cliff-New Jersey, Prentice Hall Inc.

[18] Kale, R. D., Bano, K. (1986): Field trials with vermicompost (Vee comp. E-83 UAS) on organic fertilizer. - Proc. Nation. Sem. Organic Waste Utilization, Vermicompost. -Part B, Worms and Vermicomposting, pp. 151-160.

[19] Kashiani, P., Saleh, G., Osman, M., Habibi, D. (2011): Sweet corn yield response to alternate furrow irrigation methods under different planting densities in a semiarid climatic condition. - Afric. J. Agric. Res. 6: 1032-40.

[20] Majid, M. A., Saiful Islam, M., EL-Sabagh, A., Hasan, M. K., Barutcular, C., Ratnasekera, D., Islam, M. S. (2017): Evaluation Of Growth and Yield Traits in Corn under Irrigation Regimes in Sub-Tropical Climate. - Journal of Experimental Biology and Agricultural Sciences 5(2): 143-150.

[21] Margaretha, S. L. Ningsih, Subandi dan Zubachtiroddin, W. (2014): Corn Response to N, $\mathrm{P}$ and K Fertilizers at Dry Land and Dry Climate. - Cereal Crop Research, East Lombok.

[22] Olsen, S. R., Cole, C. V., Watanabe, F. S., Dean, L. A. (1954): Estimation of Available Phosphorus in Soils by Extraction with Sodium Bicarbonate. - Circ. U.S. Dep. Agric., p. 939.

[23] Palm, A. C., Gachengo, C. N., Delve, R. J., Cadisch, G., Giller, K. E. (2001): Organic inputs for soil fertility management in tropical agroecosystems: application of an organic resource database. - Agric Ecosys Environ 83: 27-42.

[24] Patel, J. B., Patel, V. J., Patel, J. R. (2006): Influence of different methods of irrigation and nitrogen levels on crop growth rate and yield of maize (Zea mays L.). - Ind. J. Crop Sci. 1(1-2): 175-177.

[25] Pimentel, D. (1996): Green Revolution and chemical hazards. - The Sci. Total Environ. 188 (Suppl. 1): 86-98.

[26] Qasim, M., Javed, N., Himayatullah, M., Subhan, M. (2001): Effect of sewage sludge on the growth of maize crop. - Online J. Biol. Sci. 1:52-54.

[27] Randhawa, M. S., Maqsood, M., Wajid, S. A., Haq, M. A. (2012): Effect of Integrated Plant Nutrition and irrigation scheduling on yield and yield components of maize (Zea mays L.). - Pak. J. Agri. Sci. 49(3): 267-273.

[28] Rezvantalab, N., Pirdashti, H. A., Bahmanyar, M. A., Abbasian, A. (2008): Study some of yield and yield component of corn (Zea mays L.) in response to different types and rates of organic and chemical fertilizers. - J. Agric. Sci. Natural Resour. 15: 139-47.

[29] Richard, L. A. (1954): Diagnosis and Improvement of Saline and Alkaline Soils. Handbook 60, U.S. Dept. of Agriculture.

[30] SAS. (1998): Statistical Analysis Software. Version 6.12. - SAS Institute, Cary, NC, USA.

[31] Seker, C., Ersoy, I. (2005): Effects of Different Organic Manures and Leonardite on Soil Properties and Growing of Maize Plant (Zea mays L.). - S.Ü.-Journal of Agriculture Faculty 19(35): 72-83.

[32] Sharif, M., Ahmad, M., Sarir, M. S., Khattak, R. A. (2004): Effect of organic and inorganic fertilizers on the yield and yield components of maize. - Pak. J. Agri., Agri. Eng. Vet. Sci. 20: 11-16.

[33] Singh, A. K., Roy, A. K., Kaur, D. P. (2007): Effect of irrigation and NPK on nutrient uptake pattern and qualitative parameter in winter maize+ potato intercropping system. Int. J. Agric. Sci. 3(1): 199-201.

[34] Soil Survey Staff (1999): Soil Taxonomy: A Basic System of Soil Classification for Making and Interpreting Soil Surveys. - USDA-NRCS, Agriculture Handbook No: 436. U.S. Government Printing Office. p.870. 
[35] Srivastava, O. P. (1998): Integrated nutrient management for sustained fertility of soil. Indian J. Agril. Chem. 31: 1-12.

[36] TSMS. (2016): Reports of Turkish State Meteorological Service. - Ankara, Turkey.

[37] Turgut, İ. (2003): Determination of Combining Ability Effects and Heterosis By Line x Tester Analysis Method in Maize (Zea mays indentata Sturt.). - Uludağ Univ. J. of Field Crops 17(2): 33-46.

[38] Yalçın, S., Ergün, A., Özsoy, B., Yalçın, S., Erol, H., Onbaşılar, I. (2006): The effects of dietary supplementation of L-carnitine and humic substances on performance, egg traits and blood parameters in laying hens. - Asian-Aust. J. Anim. Sci. 19(10): 1478-1483.

[39] Zhang, B., Huang, G., Li, F. (2007): Effect of limited single irrigation on yield of winter wheat and spring maize relay intercropping. - Pedosphere 17: 529-37. 